\title{
COMPARING THE QUALITY OF ROUND BALERS WORK
}

Petr NOVÁK, Ph.D. ,Czech University of Life Sciences Prague, Faculty of Engineering, Kamycka 129, 16521 Prague 6 - Suchdol, Czech Republic, e-mail: novakpetr@tf.czu.cz (corresponding author)

Jiř́ MAŠEK, Ph.D., Czech University of Life Sciences Prague, Faculty of Engineering, Kamycka 129, 16521 Prague 6 - Suchdol, Czech Republic, e-mail: masekj@tf.czu.cz

Miroslav BULVA, Czech University of Life Sciences Prague, Faculty of Engineering, Kamycka 129, 16521 Prague 6 - Suchdol, Czech Republic, e-mail: bulva@tf.czu.cz

Lukáš BENEŠ, Czech University of Life Sciences Prague, Faculty of Engineering, Kamycka 129, 16521 Prague 6 - Suchdol, Czech Republic, e-mail: benes@tf.czu.cz

Forage harvest belongs to the principal works in contemporary agriculture. Increasingly popular technology is the making round bales. The basic advantage of round balers is application versatility. Harvest method is useful for making hay, straw and haylage, Quality of the bale is dependent on the level of work equipment and operator. This paper is focused on comparing the round baler with variable bale chamber. Round baler Vicon RV 1601 OC14 was compared with round baller Welger RP 435 Master. Both models were equipped with variable chamber. The variable chamber was formed by the endless belts. The evaluation was conducted from quality of work perspective and efficiency. The most important quality parameter was the density of bales. Quality parameters of bales were determined by measuring and weighing. Straw bales and haylage bales were used for studies. Qualitative indicators were converted into dry matter content. Microwave drying according to Swedish University of Agricultural Sciences was used to determine the dry matter. Baler Welger reached better qualitative parameters of work. It was also demonstrated by statistical evaluation using Tukey test. It has clearly demonstrated that round baller Welger achieves significantly greater pressing than round baller Vicon. Greater difference was measured at baling straw. Difference was below the threshold of statistical significance during haylage baling. This difference shows favour of the round baller Welger. On the other hand baler Vicon requires lower input power.

Keywords: forage crops; straw; quality parameters; round baler.

\section{INTRODUCTION}

Agriculture in the 21st century switches to greater precision of production with emphasis on quality. Of course, this also applies to the production of feed and bedding. Pick up balers are often used for production. Balers are capable of high quality production under suitable conditions (Borreani, and Tabacco, 2006). Lacefield et al. (1999) emphasizes the need good moisture of material for quality feeding. It is necessary to ensure high density of the produced bales (Han et al., 2004). Coblentz et al (1996) mentions the risk of harvest depreciation in the creation of poor quality parcels. The risk is mainly the development of mold. Damaged material can also endanger animal health. Coblentz and Hoffman. (2009) further study emphasizes the means of control for the quality of work. There is a direct correlation between bale density, moisture and its diameter. The next development step is the creation of systems to control all these parameters, while generating the yield mapping (Kroulík et al., 2010).

Yield mapping is one of the basic elements of precision agriculture system. Different sensors and systems which are mounted directly on harvesters are commonly used for yield mapping nowadays. One possibility could be weighing of the whole transport machine such as wagons. This idea is very simple but the practical application brings together technical and organizational problems. Wheeler et al. (1997) described basic yield measuring system requirements for crops yield mapping which was based on continuous weighing of wagons. Another idea for yield mapping during forage crops harvest is based on the similar principle but it is adapted for balers. Behme et al. (1997) and Wild and Aurenhammer (1997, 1999) developed this measuring system. The system was based on load measurement of the machine axle by means of strain gauges. The whole system could be completed with GPS receiver in order to create yield maps. In the future, this system could also serve to control the work of the balers (for example, sufficient density of bales).

\section{MATERIALS AND METHODS}

The Vicon RV 1601 baler is compared with the Welger RP 435 baler. Both roller balers are equipped with a variable chamber with rubber belts. Vicon baler is equipped with 5 belts, Welger has 4 pieces. Both balers are equipped 
with a cutting mechanism with 14 blades (not used). Both presses have a similar construction and bale creation method. The mean value of the recommended factory setting has always been used for the measurement.

Trial measurements were carried out in the selected field and started by pressing arranged continuous row. Measurement was carried out on the same day. Measurements took place in Makov in Eastern Bohemia Region. Both balers were operated by one driver. Balers were aggregated with Zetor tractor. Two materials were used. The first was dry wheat straw. Bale diameter $1.55 \mathrm{~m}$ was set. It was created 10 bales by each baler. Circuit of bales was measured by a measuring tape. Bale weight was measured on a platform scale.

The second material was clover (haylage production). Clover was mowed by one day in advance. Subsequently, it was rake into rows. The clover was very short, no cutting was necessary. Cutting was also not used because of the possible impact on the bale density. The entire measuring process was repeated for 10 bales from each baler. Bale diameter $1.4 \mathrm{~m}$ was set.

The measurement of dry matter was carried out according to the methodology Swedish University of Agricultural Sciences (Nyberg et al., 2002). This method allows rapid drying of the sample using microwaves. Against the conventional method (furnace drying), it significantly reduces the time required to determine the dry matter. $100 \mathrm{~g}$ of each material was used. Measurements were performed in ten replicates. Data were subsequently analyzed with utilization of software Microsoft Excel (MS Corp., USA) and Statistica 12 (Statsoft Inc., USA).

\section{RESULTS AND DISCUSSION}

Processing and comparison of the average values during the baling of haylage are described in Figure and Table 1. This table shows that the average bale of haylage from the baler Welger weighed about $147 \mathrm{~kg}$ more than the press Vicon. Weight difference is primarily due to a higher volume of bales from the press Welger. The difference in average density of haylage bales was $15.36 \mathrm{~kg} \cdot \mathrm{m}^{-3}$. The measured difference is below the threshold of statistical significance. Additionally, density values were quite different for each bale (see Figure 1). It was also demonstrated using Tukey HSD test Tukey test clearly demonstrated that the press Welger achieves greater compression than the baler Vicon, but difference was under threshold of statistical significance (one homogenous group).

The difference in the average dry matter for the period amounts to only $0.45 \%$. Bales were created almost simultaneously. Measurement error is $1.6 \%$ (Nyberg et al., 2002). Measured error is negligible. Indicator with most meahingful is density of dry matter (Dry matter in $\mathrm{m}^{3}$ ). Difference is only $5.49 \mathrm{~kg} \cdot \mathrm{m}^{-3}$. Expressed as a percentage difference is $3.14 \%$, which is not significant difference.

Table 1. Results from the measurements of haylage bales

\begin{tabular}{|l|c|c|c|c|c|c|c|}
\hline Baler & $\begin{array}{c}\text { Weight 1 bale } \\
{[\mathbf{k g}]}\end{array}$ & $\begin{array}{c}\text { Circuit of } \\
\text { bale[m] }\end{array}$ & $\begin{array}{c}\text { Volume of } \\
\text { bale }\left[\mathbf{m}^{\mathbf{3}}\right]\end{array}$ & $\begin{array}{c}\text { Density } \\
{\left[\mathbf{k g} \cdot \mathbf{m}^{-3}\right]}\end{array}$ & $\begin{array}{c}\text { Dry matter } \\
{[\mathbf{\%}]}\end{array}$ & $\begin{array}{c}\text { Dry matter } \\
\text { in } \mathbf{1 b a l e ~}[\mathbf{k g}]\end{array}$ & $\begin{array}{c}\text { Dry matter in } \\
\mathbf{~ m}^{\mathbf{3}}\left[\mathbf{k g} \cdot \mathbf{m}^{-\mathbf{3}}\right]\end{array}$ \\
\hline Vicon & 805 & 4.29 & 1.76 & 457.47 & 38.7 & 307 & 174.76 \\
\hline Welger & 951 & 4.5 & 2.01 & 472.83 & 38.3 & 363 & 180.25 \\
\hline Difference & $\mathbf{1 4 7}$ & $\mathbf{0 . 2 1}$ & $\mathbf{0 . 2 5}$ & $\mathbf{1 5 . 3 6}$ & $\mathbf{0 . 4 5}$ & $\mathbf{5 5}$ & $\mathbf{5 . 4 9}$ \\
\hline
\end{tabular}

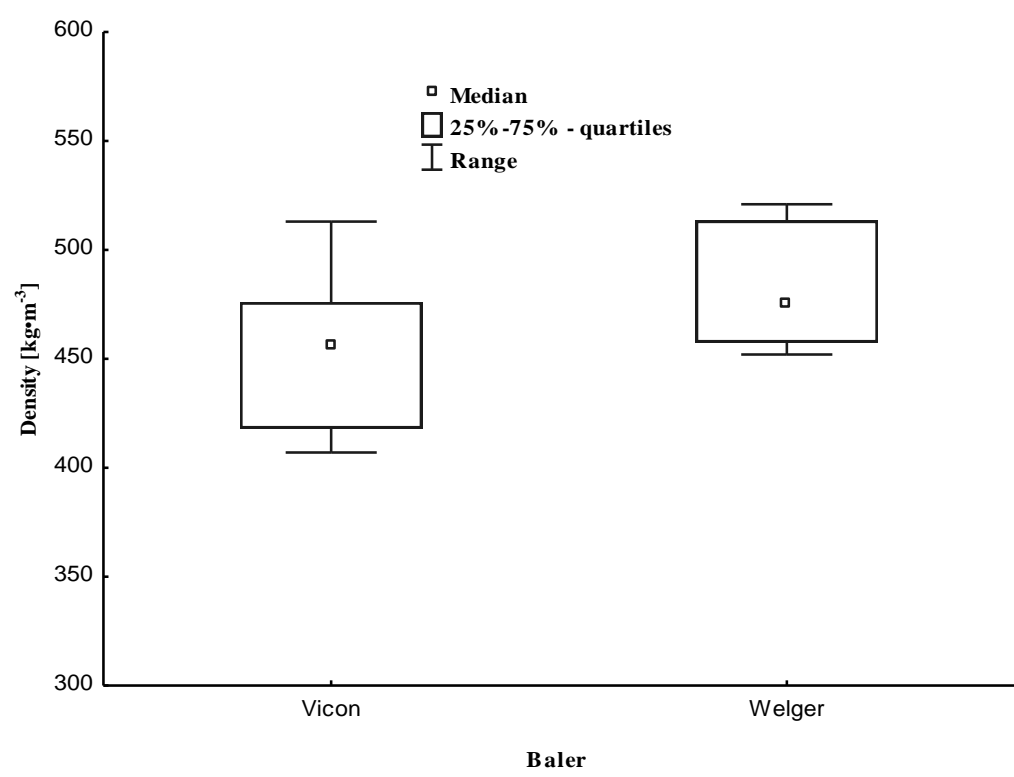

Figure 1. Density of haylage bales

Processing and comparison of the average values during the baling of straw are described in Figure 2 and Table 2. This table shows that the average bale of straw from the baler Welger weighed about $24 \mathrm{~kg}$ more than the press Vicon. The difference in average density of straw bales was $11.1 \mathrm{~kg} \cdot \mathrm{m}^{-3}$. Weight difference is primarily due to difference in 
density. The measured difference is up the threshold of statistical significance (see Table 4). Differences in bale weight were smaller in this case than during baling haylage. This is likely to be caused by the uniformity of the straw line after harvesting by the combine harvester.

Table 2. Results from the measurements of straw bales

\begin{tabular}{|l|c|c|c|c|c|c|c|}
\hline Baler & $\begin{array}{c}\text { Weight 1 } \\
\text { bale }[\mathbf{k g}]\end{array}$ & $\begin{array}{c}\text { Circuit of } \\
\text { bale[m] }\end{array}$ & $\begin{array}{c}\text { Volume of } \\
\text { bale }\left[\mathbf{m}^{\mathbf{3}}\right]\end{array}$ & $\begin{array}{c}\text { Density }\left[\mathbf{k g} \cdot \mathbf{m}^{-}\right. \\
\mathbf{3}]\end{array}$ & $\begin{array}{c}\text { Dry matter } \\
{[\mathbf{\%}]}\end{array}$ & $\begin{array}{c}\text { Dry matter in } \\
\mathbf{1 b a l e ~}[\mathbf{k g}]\end{array}$ & $\begin{array}{c}\text { Dry matter in } \\
\mathbf{m}^{\mathbf{3}} \mathbf{\text { ikg }}\left[\mathbf{m}^{-\mathbf{3}}\right]\end{array}$ \\
\hline Vicon & 255 & 5.09 & 2.47 & 103.2 & 84.7 & 216 & 87.36 \\
\hline Welger & 279 & 4.96 & 2.44 & 114.3 & 85.8 & 240 & 98.13 \\
\hline Difference & $\mathbf{2 4}$ & $\mathbf{0 . 1 3}$ & $\mathbf{0 . 0 3}$ & $\mathbf{1 1 . 1}$ & $\mathbf{1 . 1}$ & $\mathbf{2 4}$ & $\mathbf{1 0 . 7 7}$ \\
\hline
\end{tabular}

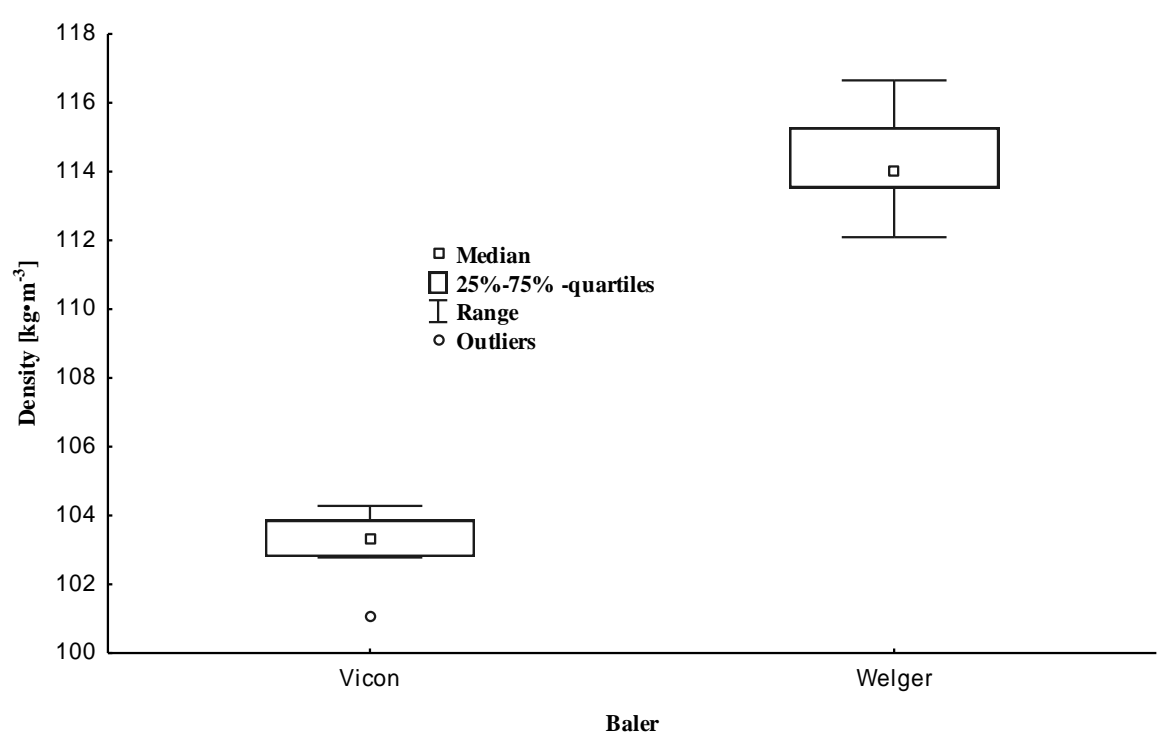

Figure 2. Density of straw bales

Similar studies have focused on the quality of bales, especially for haylage. The need for high density bales is already described by Robertson (1983). The quality of the package and the compression rate are also described by Rotz (1994). This study also highlights the effect on long-term storage. Greater density also reduces the loss of feed quality. In his study, it is proved by Harrigan and Rotz (1994). They have evaluated several months of hay storage. The quality of compression is also emphasized by Kawamoto et al. (2007). In their study, they evaluated the silage from the rice during the several months of storage. .Xianping (2003) describes design adjustments to achieve a density above $120 \mathrm{~kg} . \mathrm{m}^{-}$ ${ }^{3}$. Xu et al (2010) describe the problem of the effect of mechanical systems on parts of plants. Shito et al. (2006) highlight the quality of feed from roller bales. In his work describes the design change for bale production from maize. At the same time, the material must not be damaged during compression. This is important for all processed materials.

\section{CONCLUSIONS}

1. The quality of work of machines for harvesting equipment has long been little researched topic.

2. However, quality of work is the primary aspect of the resulting quality of feed. Greater density of bales figuratively means better quality of silage.

3. In the case of straw harvesting, density does not affect to quality of the product. The difference in average density of haylage bales was $15.36 \mathrm{~kg} \cdot \mathrm{m}^{-3}$. Greater bale density means cost savings in this case as well. A smaller number of bales mean lower logistics costs and also saving packaging materials. We cannot forget the environmental aspect (less plastic waste).

4. The difference in quality of work between the two rated balers was demonstrated. Factory settings were used during the measurement for both balers. Statistically significant differences were detected at harvest straw. Density values were almost identical during harvesting silage. The difference in average density of straw bales was $11.1 \mathrm{~kg} \cdot \mathrm{m}^{-3}$

5. Both presses have demonstrated the ability of quality work at harvest dry (straw) and wet (haylage) materials.

\section{ACKNOWLEDGEMENTS}

Supported by the CULS Prague - Project no. 2015:31160/1312/3110

\section{REFERENCES}

1. Behme, J.A., Schinstock, J.L., Bashford, L.L., Leviticus, L.I., 1997. Site-Specific Yield for Forages. St. Joseph, ASAE Paper No. 971054.

2. Borreani, G., Tabacco, E., 2006. The effect of a baler chopping system on fermentation and losses of wrapped big bales of alfalfa. Agronomy Journal, Vol. 98(1), pp. 1-7. https://doi.org/10.2134/agronj2004.0134 
3. Coblentz, W. K., Fritz, J. O., Bolsen, K. K., Cochran, R. C., 1996, Quality Changes in Alfalfa Hay During Storage in Bales1. Journal of Dairy Science, Vol. 79(5), pp. 873-885. https://doi.org/10.3168/jds.S0022-0302(96)76436-6

4. Coblentz, W. K., Hoffman, P. C.,2009. Effects of bale moisture and bale diameter on spontaneous heating, dry matter recovery, in vitro true digestibility, and in situ disappearance kinetics of alfalfa-orchardgrass hays. Journal of Dairy Science, Vol. 92(6), pp. 2853-2874.https://doi.org/10.3168/jds.2008-1920

5. Han, K. J., Collins, M., Vanzant, E. S., Dougherty, C. T., 2004. Bale density and moisture effects on alfalfa round bale silage. Crop Science, vol. 44(3), pp. 914-919. https://doi.org/10.2135/cropsci2004.9140

6. Harrigan, T. M., Rotz, C. A., 1994. Net, plastic, and twine-wrapped large round bale storage loss. Applied Engineering in Agriculture, Vol. 10(2), pp. 189-194. https://doi.org/10.13031/2013.25840

7. Kawamoto, H., Otani, R., Oshibe, A., Yamaguchi, H., Deguchi, S., Tanaka, O., Watanabe, H., 2007. Ensilage of wilted whole crop rice (Oryza sativa L.) using a roll baler for chopped material: Silage quality in long-term storage. Grassland Science, Vol. 53(2), pp. 85-90.

8. Kroulík, M., Mašek, J., Kvíz, Z., Prošek, V. , 2010. Sensor connection for yield determination on round balers with variable chamber. Landtechnik, 231-237.

9. Lacefield, G., Henning, J. C., Collins, M., Swetnam, L., 1999. Quality hay production. Cooperative Extension Service, University of Kentucky, Collage of Agriculture, Lexington.

10. Nyberg, A., Strömberg, J., Stenberg, M., Stenberg, B., Nadeau, E., 2002. Snabbmetoder för bestämning av torrsubstans i grönmassa och ensilage, $15 \mathrm{p}$ (in Swedish).

11. Robertson, J. A., 1983. Influence of harvesting and conservation practices on forage quality. Canadian Journal of Plant Science, 63(4), pp. 913-925. https://doi.org/10.4141/cjps83-115

12. Rotz, C. A., Muck, R. E., 1994. Changes in forage quality during harvest and storage. Forage quality, evaluation, and utilization,), pp. 828-868.

13. Shito, H., Yamana, N., Shibuya, Y., Takahashi, K.,2006. Development of the roll baler for chopped materials. Japan Agricultural Research Quarterly, Vol. 40(3), pp. 233-237. https://doi.org/10.6090/jarq.40.233

14. Wheeler P., Godwin R.J., Watt C.D., Blackmore B.S., 1997. Trailer Based Yield Mapping. In: Stafford J.V. (ed.), 1st European Conference on Precision Agriculture. Oxford, UK, BIOS Scientific Publishers, pp. 751-758.

15. Wild K., Auernhammer H., 1997. Dynamic Weighing in a Round Baler for Local Yield Measurement. St. Joseph, ASAE Paper No. 971055.

16. Wild K., Auernhammer H., 1999. A weighing system for local yield monitoring of forage crops in round balers. Computers and Electronics in Agriculture, Vol. 23, pp. 119-132. https://doi.org/10.1016/S0168-1699(99)00026-5

17. Xiangping, L., 2003. 4LSK-50 wheat straws combine baler. Transactions of the Chinese Society of Agricultural Engineering, Vol. 19(1), pp. 107-109.

18. Xu, C. M., Wang, C. Y., Chen, F., Lei, M., Jiang, Y. X., Teng, H. D., 2010, The measurement of dynamic stress for the top-cutter machine of cotton. In Applied Mechanics and Materials, Vol. 34, pp. $1323-1327$. https://doi.org/10.4028/www.scientific.net/AMM.34-35.1323 